\title{
Analisis Dampak Pengelolaan dan Penggunaan Dana Desa terhadap Pembangunan Daerah
}

\section{Analysis of the Impact of Management and Use of Village Funds on Regional Development}

\author{
Yanhar Jamaluddin*, Asep Sumaryana, Budiman Rusli \& Rd. Ahmad Buchari \\ Program Pascasarjana Ilmu Administrasi, \\ Fakultas Ilmu Sosial dan Ilmu Politik, Universitas Padjadjaran, Indonesia
}

\begin{abstract}
Abstrak
Artikel ini dimaksudkan untuk menganalisis dampak pengelolaan dan penggunaan Dana Desa terhadap pembangunan daerah. Hal ini disebabkan oleh karena pengelolaan Dana Desa tidak tepat sasaran dan penggunaannya belum optimal. Metode penelitian yang digunakan adalah dengan pendekatan kualitatif. Hasil analisis menunjukkan bahwa pengelolaan dan penggunaan Dana Desa tidak memberi dampak signifikan bagi pertumbuhan pembangunan daerah dan program pembangunan Desa tidak sinkron dengan kebijakan pembangunan Daerah (RPJM Daerah). Dampak ini disebabkan oleh karena Desa memiliki kewenangan luas dalam menentukan rencana programnya dan daerah kurang memiliki wewenang mengintegrasikan kebijakan program pembangunan. Untuk mengintegrasikan program pembangunan Desa yang sinkron dengan kebijakan pembangunan Daerah, diperlukan intervensi regulation Pemerintah Daerah guna mengarahkan program Desa, mengacu pada kebijakan pembangunan Daerah.
\end{abstract}

Kata Kunci : Dampak, Kebijakan, Dana Desa, Pembangunan Daerah

\begin{abstract}
This article is intended to analyze the impact of management and use of the Village Fund on regional development. This is due to the fact that the management of the Village Fund is not well targeted and its use is not yet optimal. The research method used is with qualitative approach. The results of the analysis show that the management and use of the Village Fund does not have a significant impact on the growth of regional development and the village development program is not in sync with the Regional development policy (RPJM Daerah). This impact is caused by the fact that the Village has wide authority in determining the program plan and the regions lack the authority to integrate development program policies. To integrate Village development programs that are in sync with the Regional development policy, regulation intervention by Local Government is required to direct the Village program, referring to Regional development policy.
\end{abstract}

Keywords: Impact, Policy, Village Fund, Regional Development

How to Cite: Jamaluddin, Y. Sumaryana, A. Rusli, B. \& Buchari, R.A. (2018). Analisis Dampak Pengelolaan dan Penggunaan Dana Desa terhadap Pembangunan Daerah. JPPUMA: Jurnal Ilmu Pemerintahan dan Sosial Politik UMA, 6 (1): 14-24

${ }^{*}$ Corresponding author: ISSN 2549-1660 (Print)

E-mail: yanhar15001@mail.unpad.ac.id ISSN 2550-1305 (Online) 


\section{PENDAHULUAN}

Kebijakan Dana Desa ditetapkan pemerintah melalui Peraturan Pemerintah No. 60 Tahun 2014 tentang Dana Desa yang bersumber dari Anggaran Pedapatan dan Belanja Negara. Kebijakan ini dimaksudkan untuk mewujudkan Desa kuat, maju, mandiri, dan demokratis, sehingga untuk itu peran dan potensi Desa harus diberdayakan.

Sebelum kebijakan dana Desa ini ditetapkan, telah ada satu kebijakan yang pada hakekatnya adalah untuk membiayai bidang pemerintahan, pembangunan dan kemasyarakatan Desa, seperti Alokasi Dana Desa (ADD). Program ADD muncul sejak dikeluarkannya Undang-Undang Nomor 32 Tahun 2004, dimana ADD dialokasikan bersumber dari Anggaran Pendapatan dan Belanja Daerah. Sebelum program ADD telah ada program Dana Bantuan Desa bergulir sejak tahun 1969 yang disediakan pemerintah pusat dalam bentuk Inpres Pembangunan Desa (Solekhan, 2014). Dengan demikian, kebijakan Dana Desa merupakan kebijakan baru hasil dari pengembangan kebijakan sebelumnya yang diarahkan untuk meningkatkan kesejahteraan masyarakat Desa, kualitas hidup manusia, serta penanggulangan kemiskinan.

Ditinjau dari tujuannya, Kebijakan Dana Desa memiliki kesamaan seperti di Myanmar (2011) disebut dengan kebijakan Local Development Funds (Robertson et.al. 2015). Kebijakan Local Development Funds/LDFs sebagai rangkaian reformasi pembangunan berbasis "peoplecentered" dan "bottom-up approach" yang lebih banyak menitikberatkan pada perencanaan dan penganggaran pemerintah. Secara khusus, $L D F s$ adalah untuk mengidentifikasi dan mendanai proyek pengembangan masyarakat. LDFs merupakan kebijakan fiskal yang dilakukan melalui transfer Dana antar pemerintah, dengan memberikan Dana pembangunan langsung kepada pemerintah daerah dan masyarakat. LDFs digunakan untuk mendanai proyek infrastruktur berskala kecil seperti jembatan dan jalan penghubung antar Desa, proyek drainase, air minum dan irigasi. Proyek-proyek yang dibiayai $L D F s$ harus disesuaikan dengan kebutuhan masyarakat dan penggunaannya dikelola di bawah pengawasan pemerintah daerah dan komite pengelolaan Dana yang dipilih ditingkat lokal (Robertson, et.al. 2015). Sedangkan di Laos disebut Village Development Funds atau VDCs bersifat bantuan lunak bersumber dari Bank Dunia dan Pemerintah Finlandia, bertujuan untuk pengentasan kemiskinan (Paavola, 2012).

Kebijakan dana Desa telah diimplementasikan sejak tahun anggaran 2015. Hingga 2017 pemerintah telah mengalokasikan pagu Dana Desa bersumber dari APBN sebesar 127,6 Triliun rupiah untuk 74.954 Desa di Indonesia. Pada tahun anggaran 2015 teralokasi sebesar 20,7 Triliun rupiah

(http://www.tribunnews.com/nasional/2015 $>$ [04/16/2016]), 2016 sebesar 46,9 Triliun rupiah

(http://www.kemenDesa.go.id/index.php/vie $\mathrm{w} /$ detil/1679 /penggunaan-danaDesa $>[04 / 13 / 2016])$, dan tahun 2017 sebesar 
60 Triliun

(http://www.djpk.depkeu.go.id/wpcontent/uploads/2016/11/RINCIANALOKASI-DANA-DESA-TA-2017-UPLOAD.pdf> [06/04/2017]).

Menurut informasi dan data, banyak fenomena terjadi baik keberhasilan maupun ketidakberhasilan dalam pengelolaan dan penggunaan dana Desa tersebut. Seperti Desa Ponggok Kabupaten Klaten - Jawa Tengah, dinilai berhasil dikarenakan : a. Dana Desa digunakan untuk pengembangan BUMDes dan pembangunan infrastruktur, b. komitmen kuat dari pimpinan dan masyarakat (https://bisnis.liputan6.com/ponggok_jadi_co ntoh_keberhasilan $>[11 / 04 / 2017])$, kemudian Desa Kalukubula Kecamatan Biromaru Kabupaten Sigi - Sulawesi Tengah, keberhasilannya ditentukan karena : a. Melibatkan seluruh elemen, komponen dan aparat di Desa, b. Transparan kepada masyarakat, c. menggunakan dana sesuai perencanaan

(https://sulteng.antaranews.com/desa_kaluku bula_pengelola_dana_desa_terbaik $>[11 / 04$ /2017]), dan Desa Labuhan Ratu Baru Kecamatan Way Jepara Kabupaten Lampung Timur - Lampung, keberhasilannya ditentukan oleh: a) Dukungan Sistem Keuangan yang baik; b) pemanfaatan dana Desa sepenuhnya bagi kepentingan warga (https://kupastuntas.co/labuhan_ratu_baru_di _lampung_timur $>[11 / 04 / 2017])$. Namun ditemukan pula ketidakberhasilan pengelolaan dan penggunaan Dana Desa, seperti hasil investigasi Komisi Pemberantasan Korupsi
(KPK) - 2015, menyimpulkan "Pencairan Dana Desa tidak sesuai peruntukan disebabkan perangkat desa kurang memahami peruntukkan penggunaan Dana Desa“ (http://news.liputan6.

com/read/2342666/kpk-banya-dana-desatidak-sesuai-peruntukkannya>[10/17/2015]). Selanjutnya hasil penelitian Pusat Telaah dan Informasi Regional (2016) menyimpulkan "Kucuran Dana Desa tidak memberikan hasil yang signifikan bagi pembangunan Desa, $6 \%$ Dana Desa dipergunakan tidak sesuai peruntukkannya selama tahun 2015 “ (http://Liputan6.com>[03/10/2016]), dan implementasi pengelolaan Dana Desa belum memenuhi asas partisipatif, transparansi, dan akuntabilitas (Jamaluddin, 2016). Kemudian, hasil survey Pusat Kajian dan Pendidikan dan Pelatihan Aparatur-I (PKP2A-1) Lembaga Administrasi Negara RI (2017), mengidentifikasi tantangan dan permasalahan dalam pengelolaan dan penggunaan dana Desa di Indonesia, antara lain: a) Sumberdaya manusia masih belum memahami fungsi, tujuan serta manfaat anggaran yang diberikan pemerintah; b) Pengelolaan dan Penggunaan Dana Desa tidak tepat sasaran sesuai aturan pemerintah dan daerah; c) Proporsi pengelolaan dan penggunaan Dana Desa masih dialokasikan pada kegiatan fisik bukan nonfisik; d) Regulasi yang kontradiktif antara Pemerintah pusat (Kemendagri, KemendesPDTT) dengan Pemerintah Daerah (Perbup); e) Belum adanya road-map terkait kebijakan Dana Desa untuk jangka pendek, menengah, dan panjang; f) Rendahnya pelibatan 
masyarakat dalam pengelolaan Dana Desa, dan kepercayaan masyarakat terhadap aparatur pelaksana masih kurang. Permasalahan ini pun erat kaitannya ketika Menteri Desa dan PDTT dalam sebuah seminar di FISIP UGM Yogyakarta - Maret 2017 menyatakan “Pengelolaan dana Desa yang melibatkan tiga kementerian berbeda, menimbulkan adanya tumpang tindih dalam pelaksanaan fungsi masing-masing

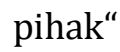

(https://suara.com/bisnis/pengelola_ dana_desa>[11/04/2017]).

Berdasarkan fenomena tersebut, dapat disimpulkan bahwa masih terdapat banyak permasalahan dalam pengelolaannya masih tidak tepat sasaran dan penggunaan Dana Desa belum optimal. Artikel ini disusun bertujuan untuk menganalisis bagaimana dampak pengelolaan dan penggunaan Dana Desa terhadap pembangunan daerah. Analisis data menggunakan pendekatan kualitatif; "refers to the meaning, concepts, defenition, characterictics, metaphors, symbols, and description of things" (Berg, 2007). Instrumen analisis menggunakan dampak (Indiahono, 2017). Analisis dampak adalah untuk mengkaji akibat-akibat pelaksanaan kebijakan dan membahas hubungan antara cara-cara yang digunakan dan hasil yang hendak dicapai (Lineberry, 1977 dikutip Rusli, 2014).

\section{PEMBAHASAN}

Proses perumusan kebijakan dana Desa melibatkan aktor internal birokrasi yaitu Kementerian Desa, Pembangunan Daerah Tertinggal dan Transmigrasi; atau menurut
Anderson disebut official policymakers. Official Policy-Makers adalah aktor kebijakan yang secara formal memiliki legal authority - yaitu legislatif, eksekutif, administrator, dan hakim (Anderson, 1979: 34, 1984: 34). Rumusan kebijakan ini disusun berdasarkan pasal 72 ayat (1) huruf b dan ayat (2) Undang-Undang No. 6 Tahun 2014 tentang Desa; dimana "salah satu sumber pendapatan Desa berasal dari alokasi Anggaran Pendapatan dan Belanja Negara".

Kebijakan Dana Desa yang mengatur pengelolaan dan penggunaan dana Desa, dibuat oleh pemerintah (Negara), membuktikan kalau Negara punya otoritas Monopoli (yang tidak dimiliki institusi lain) untuk mendistribusikan kepentingannya terhadap Desa. Alhasil, kedudukan Desa dinilai sebagai komoditi publik atau resources bagi Negara untuk menyelenggarakan kepentingan pemerintahan dan pembangunan (Jamaluddin, 2016 - ICMR). Kepentingan yang dimaksud dalam konteks bentuk kebijakan disebut kebijakan distributive yaitu melakukan distribusi atau memberikan akses yang sama terhadap sumberdaya tertentu (Keban, 2005). Dengan demikian kebijakan dana Desa hakekatnya merupakan wujud keinginan pemerintah Pusat mengalokasikan anggaran untuk percepatan pembangunan di Desa. Melalui distribusi anggaran itu pada sisi lain untuk memenuhi komitmen ekonomi politik Nawa Cita Joko Widodo - Jusuf Kalla yaitu "Membangun Indonesia dari pinggiran", dengan menjadikan Desa sebagai basis penerima otoritas kekuasaan langsung dari 
pemerintah. Dengan keinginan ini, menjadikan kebijakan Dana Desa sebagai hasil restrukturisasi proses pembuatan keputusan sehingga mempengaruhi pilihan-pilihan aktor di pemerintahan (Jamaluddin, 2016), terutama dalam mendorong pertumbuhan pembangunan di daerah.

Pemerintah Desa dan Pemerintah Daerah sebagai aktor pelaksana kebijakan untuk mengelola dan menggunakan dana Desa, memiliki kewenangan yang saling berbeda. Kewenangan Pemerintah Desa diantaranya:

1. Menerima pengalokasian Dana Desa

2. Menggunakan Dana Desa yang diprioritaskan untuk membiayai Pembangunan Desa dan Pemberdayaan Masyarakat Desa.

3. Mengajukan RKPDes dan APBDes

4. Mempertanggungjawabkan penggunaan Dana Desa

5. Menyerahkan laporan realisasi penggunaan Dana Desa kepada Bupati/Walikota

Sedangkan kewenangan Pemerintah Daerah, antara lain:

1. Membuat dan menetapkan kebijakan taktis operasional berupa Peraturan Bupati/Walikota tentang Tatacara Pembagian dan penetapan rincian besaran Dana Desa pada setiap Desa.

2. Menyalurkan Dana Desa dari RKUD ke RKD

3. Menyampaikan laporan realisasi penyaluran dan konsolidasi penggunaan Dana Desa kepada Menteri Keuangan cq. Mendagri, Mendes-PDTT, dan Gubernur.
4. Memberikan persetujuan jika Dana Desa digunakan untuk membiayai kegiatan yang tidak diprioritaskan

Perbedaan wewenang tersebut semakin terlihat ketika kebijakan Dana Desa diimplementasikan. Peran dan kewenangan Pemerintah Desa lebih dominan dalam menentukan program pembangunan dan pemberdayaan masyarakat yang disusun berdasarkan aspirasi masyarakat dan kebutuhan Desa. Seperti kasus di Kabupaten Garut Provinsi Jawa Barat, pada kenyataannya Pemerintah Kabupaten tidak memiliki kewenangan untuk meng-intervensi program pembangunan Desa agar memperhatikan kebijakan program pembangunan Daerah. Konsekuensinya, selama 3 tahun Dana Desa dialokasikan ke 421 Desa atau sebesar $763,375,004,000.00$ miliar rupiah (DPMD Kabupaten Garut, 2017), program-program yang telah dilaksanakan di Desa tidak sinkron dengan kebijakan pembangunan Daerah. Hal ini disebabkan Desa bergerak menurut RPJMDes-nya masing-masing sehingga program pembangunan di Desa tidak terintegrasi dengan kebijakan pembangunan Daerah, bahkan menimbulkan persaingan program diantara Desa. Sementara di sisi lain Daerah tidak punya wewenang intervensi untuk mengarahkan penggunaan Dana Desa itu agar terintegrasi sesuai kebijakan pembangunan daerah. Kewenangan daerah hanya sebatas "mengarahkan" bukan "memaksa" sehingga berakibat kebijakan dan program pembangunan Desa pun tidak memperhatikan kebijakan dan program 
pembangunan daerah. Oleh sebab itu dalam mengelola dan menggunakan dana Desa, Desa punya kewenangan luas untuk menentukan program pembangunan sesuai dengan rencana. Kewenangan luas yang dimiliki Desa diatur berdasarkan pasal 19 Undang-Undang Nomor 6 Tahun 2014 tentang Desa, menyebutkan bahwa Kewenangan Desa meliputi:

1. Kewenangan berdasarkan hak asal usul;

2. Kewenangan lokal berskala Desa;

3. Kewenangan yang ditugaskan oleh Pemerintah, Pemerintah Daerah Provinsi, atau Pemerintah Daerah Kabupaten/Kota; dan

4. Kewenangan lain yang ditugaskan oleh Pemerintah, Pemerintah Daerah Provinsi, atau Pemerintah Daerah Kabupaten/Kota sesuai dengan ketentuan peraturan perundang-undangan;

Intervensi menjadi sesuatu yang penting sebagai alat untuk mengintegrasikan kebijakan pembangunan Desa dengan kebijakan pembangunan Daerah. Dalam arti lain, bagaimana dengan adanya intervensi, daerah memiliki hak dan porsi untuk memaksa desa agar mengakomodir prioritas kebijakan pembangunan Daerah untuk dilaksanakan di Desa atau menjadi bagian dari kebijakan pembangunan Desa. Dengan demikian secara tidak langsung kebijakan penggunaan dana Desa memberi konstribusi terhadap upaya mewujudkan pertumbuhan pembangunan sesuai RPJM Daerah. Intervensi dan kaitannya dengan peranan pemerintahan terhadap kehidupan rakyat pada umumnya dilakukan melalui empat instrumen, yakni: provision, subsidy, production, and regulation (Hughes, 1998 dalam Setiyono, 2014). Dari keempat instrumen itu, instrumen regulation sangat tepat untuk melekatkan intervensi daerah kepada Desa dalam melaksanakan kebijakan Dana Desa.

Regulation, yakni pemerintah menggunakan kekuatan memaksa untuk mengijinkan atau melarang aktivitas tertentu. Alat untuk mengijinkan dan melarang berbagai aktivitas diatur dalam regulasi dan peraturan (Hughes, 1998 dalam Setiyono, 2014). Konkritnya, Intervensi regulation yang dimaksud secara implisit adalah perubahan terhadap Peraturan Pemerintah No. 60 Tahun 2014 tentang Dana Desa yang bersumber dari APBN - pasal 20 yang berbunyi "Penggunaan Dana Desa mengacu pada Rencana Pembangunan Jangka Menengah Desa dan Rencana Kerja Pemerintah Desa" dengan menambahkan "dengan memperhatikan arah kebijakan dan prioritas pembangunan Kabupaten/Kota“. Perubahan pada pasal ini pun sesuai dengan Peraturan Pemerintah No. 43 Tahun 2014 tentang Peraturan Pelaksana Undang Undang No 6 Tahun 2014 Tentang Desa, pasal 116 (5) yang berbunyi "Rancangan RPJM Desa sebagaimana dimaksud pada ayat (4) memperhatikan arah kebijakan perencanaan pembangunan Kabupaten/Kota; dan pasal 117 (1) yang berbunyi "RPJM Desa mengacu pada RPJM Kabupaten/Kota; dan (3) yang berbunyi“ RPJM Desa disusun dengan mempertimbangkan kondisi objektif Desa dan prioritas pembangunan Kabupaten/Kota “. 
Produk yang dihasilkan dari penggunaan Dana Desa merupakan barang publik dan dikonsumsi secara luas oleh masyarakat, seperti jalan - jembatan - irigasi, fasilitas pendidikan - kesehatan, dan lain-lain. Namun permasalahannya, apakah setelah barang publik tersebut diproduksi, bermanfaat bagi masyarakat dan makin membaiknya pelayanan kepada publik? Padahal outcome dari penggunaan Dana Desa adalah mencoba mendekatkan layanan Negara untuk mewujudkan kesejahteraan masyarakat Desa. Peran "Negara" idealnya berkewajiban menyelenggarakan pelayanan maksimal kepada masyarakat. Sangatlah tepat seperti disebutkan Weber dikutip Ostrom (1973), dalam Fredericksen (2012); "fungsionaris administrative adalah pelayan publik, bukan elit teknokratik sebagai tuan“. Ini berarti, kedudukan Negara selaku Produsen memiliki hak otoritas monopoli pengendalian terhadap Desa, dan berperan sebagai pelayan guna memenuhi kebutuhan dan mengatasi permasalahan masyarakat, bukan sebagai "Tuan" atau pemilik.

Kebijakan Dana Desa yang mengatur pengelolaaan dan penggunaan dana Desa merupakan produk dari Negara, sedangkan locusnya berada di wilayah terendah pada Pemerintah Desa. Mengapa di Desa? sebab Desa merupakan wilayah monocentric; yaitu terpisah/otonom, Multi aturan yang lebih dapat menghasilkan produk barang/jasa publik yang murah dan baik daripada pada wilayah polycentric (Sentral/terpusat, hukum tunggal). Maknanya; Desa sebagai institusi terendah merupakan tingkatan pertama yang langsung bersentuhan dengan urusan layanan primer publik dan sebagai institusi penerima dampak kebijakan. Oleh sebab itu, pada bagian ini penulis mencoba mengidentifikasi dampak (manfaat ataupun kerugian) dari pengelolaan dan penggunaan Dana Desa terhadap pembangunan daerah, seperti pada tabel berikut:

Tabel 1. Identifikasi Dampak Pengelolaan dan Penggunaan Dana Desa

\begin{tabular}{|c|c|}
\hline Manfaat (ideal) & Kerugian (realita) \\
\hline $\begin{array}{l}\text { Dana Desa sebagai sumberdaya untuk } \\
\text { mensinergikan program Pembangunan Nasional } \\
\text { - Provinsi-dan daerah. } \\
\text { Dana Desa menjadi motivasi masyarakat Desa } \\
\text { untuk kembali atau tetap di Desa untuk } \\
\text { membangun Desa melalui program padat karya } \\
\text { dengan memanfaatkan potensi desa dan } \\
\text { memberdayakan kemampuan } \\
\text { (SWAKELOLA) } \\
\text { Kebijakan dana Desa mengandung nilai } \\
\text { ekonomis dan politis. Secara ekonomis; dengan } \\
\text { meningkatnya infrastruktur mendorong } \\
\text { produktivitas masyarakat dalam mengelola } \\
\text { potensi yang dimiliki. Secara politis memacu } \\
\text { kesadaran masyarakat akan haknya ikut terlibat } \\
\text { dalam pemerintahan dan pembangunan. }\end{array}$ & $\begin{array}{l}\text { Desa kesulitan mempertanggungjawabkan penggunaan } \\
\text { Dana mengikuti format laporan APBN. } \\
\text { Penggunaan dana tidak tepat peruntukkannya. } \\
\text { Aktor pusat semakin sulit mengawasi penggunaan anggaran. } \\
\text { Kalau pun dilakukan melalui direct control, berimplikasi } \\
\text { terhadap makin membesarnya sumberdaya (manusia dan } \\
\text { anggaran) untuk kegiatan pemantauan dan evaluasi. } \\
\text { Desa menjalankan program menurut RPJMDes-nya dan } \\
\text { kurang memperhatikan kebijakan pembangunan daerah. } \\
\text { Karena Desa memiliki kewenangan yang ditugaskan oleh } \\
\text { Pemerintah berdasarkan UU Desa. } \\
\text { Dengan kewenangan itu tercipta ego-sektoral setiap Desa, } \\
\text { sehingga terjadi persaingan antar Desa, dan tidak } \\
\text { munculnya sinkronisasi program untuk mendorong } \\
\text { pencapaian prioritas pembangunan kawasan dan daerah. } \\
\text { Pemerintah Daerah kurang memiliki power terhadap } \\
\text { penggunaan Dana Desa. Daerah hanya berwenang } \\
\text { memantau dan mengevaluasi. } \\
\text { Pembangunan Desa tidak terintegrasi dengan arah dan } \\
\text { kebijakan pembangunan Daerah. }\end{array}$ \\
\hline
\end{tabular}


Berdasarkan identifikasi tersebut, dampak yang sangat menonjol dalam pengelolaan dan penggunaan Dana Desa adalah Desa dengan kewenangannya cendrung "berdiri sendiri" dan daerah kesulitan untuk mengintegrasikan antara program Desa dengan Kebijakan Daerah. Padahal RPJMDesa disusun dengan memperhatikan arah kebijakan pembangunan kabupaten/kota, atau dengan kata lain RPJM Desa mengacu pada RPJM Kabupaten/Kota. Namun kenyataannya hal tersebut tidak terimplementasi sehingga pembangunan Desa tidak mendorong terwujudnya pertumbuhan pembangunan daerah. Kebijakan Dana Desa sebenarnya dapat menjadi pendorong untuk mendukung pencapaian program pembangunan daerah. Namun masalahnya sasaran pelaksanaan kebijakan penggunaan Dana Desa bukanlah Daerah tetapi Desa.

Bagi masyarakat, dampak perubahan yang diharapkan dari suatu kebijakan pada umumnya adalah "untuk menciptakan perubahan dalam kehidupan masyarakat" (Makmur, 2015: 84). Karenanya, perubahan yang diharapkan masyarakat dalam pengelolaan dan penggunaan dana Desa seperti kasus di Kabupaten Garut, adalah:

1. Tercapainya kesejahteraan masyarakat dan berkembangnya BUMDes. Namun tantangan mewujudkan harapan tersebut harus diikuti dengan meningkatnya konsolidasi internal di Desa antara masyarakat - Kepala Desa - dan Badan Permusyawaratan Desa (BPD). Artinya bahwa dalam mengelola dan menggunakan dana Desa bukan hanya otoritas dari Kepala Desa (walaupun sebagai penguasa di Desa), namun harus melibatkan unsurunsur masyarakat dan BPD, mulai dari menyusun hingga mengawasi program.

2. Meningkatnya infrastruktur Desa dan peringkat Indeks Pembangunan Manusia (IPM). IPM dimaksudkan untuk menjelaskan bagaimana penduduk dapat mengakses hasil pembangunan dalam memperoleh pendapatan, kesehatan, pendidikan, dan sebagainya. IPM dibentuk atas tiga dimensi dasar, yaitu; umur panjang dan hidup sehat; pengetahuan; dan standard hidup layak. Artinya bahwa pemanfaatan yang sebesar-besarnya dari dana Desa untuk kepentingan masyarakat bukan hanya pembangunan fisik tetapi juga pembangunan non-fisik yaitu peningkatan kualitas manusia.

3. Mendorong pertumbuhan pembangunan daerah dan sinkronnya pembangunan Desa berdasarkan Rencana Tata Ruang dan Wilayah (RTRW) daerah. Jumlah Dana Desa yang diterima dalam jumlah besar sebenarnya dapat mendorong percepatan pembangunan daerah, mengingat Daerah juga memiliki keterbatasan sumberdaya keuangan. Sehingga Dana Desa diharapkan dapat menjadi sugesti mendorong pertumbuhan pembangunan daerah dan pemanfaatan Dana Desa akan sinkron dengan kebijakan pembangunan Daerah.

Selanjutnya Dampak nyata dari kebijakan dana Desa bagi masyarakat dan pembangunan, diantaranya: 
1. Sarana-prasarana Desa seperti jalan desa, penyulingan air dan irigasi "lebih mumpuni" sehingga meningkatkan kesejahteraan masyarakat terutama petani.

2. Semakin giatnya kegiatan ekonomi masyarakat Desa, ditandai dengan tumbuh dan berkembangnya Badan Usaha Milik Desa (BUMDesa), sedangkan disisi lain memudarnya semangat gotong royong tetapi partisipasi masyarakat melalui prinsip swakelola meningkat.

3. Dampak psikologisnya; mendorong warga menjadi calon untuk mengikuti pemilihan Kepala Desa, dengan harapan terpilih menjadi Kepala Desa. Namun dengan makin banyaknya calon Kepala Desa ternyata berimplikasi terhadap terkelompok-kelompoknya masyarakat.

Jika dilihat antara apa yang diharapkan dengan hasilnya, maka yang lebih ironis (seperti di Kabupaten Garut); pertumbuhan ekonomi secara menyeluruh masih kecil atau tidak memberi dampak yang signifikan bagi pembangunan daerah dan tidak mendukung RTRW Daerah. Penyebabnya adalah, Desa selama menggunakan Dana Desa masih berpikir parsial (berpikir tentang desanya saja) sehingga dampak dari Dana Desa belum memenuhi harapan. Harapannya adalah adanya integrasi program, integrasi kebijakan, dan integrasi wilayah antara Desa dan Daerah, sehingga hasilnya signifikan bagi pembangunan daerah. Integrasi kebijakan juga dapat dipahami produknya sebagai kebijakan integrasi, adalah adanya kesepakatan untuk menyatukan kebijakan menjadi satu kebijakan tunggal (Nugroho, 2016: 84). Artinya, kedua kebijakan dan prioritas program Desa dan Daerah, diselaraskan menjadi satu kesepakatan dalam bingkai kebijakan bersama. Jika penyelarasan dapat dilakukan, hasilnya akan lebih signifikan terhadap kemajuan pembangunan daerah.

Beberapa dampak nyata di masyarakat menggambarkan sebuah konsekuensi dari pengelolaan dan penggunaan Dana Desa, karena sesungguhnya "Implementasi suatu kebijakan dalam pengertian yang luas merupakan alat administrasi hukum dimana berbagai aktor, organisasi, prosedur, dan teknik yang bekerja bersama-sama untuk menjalankan kebijakan guna meraih dampak atau tujuan yang diinginkan" (Lester \& Stewart, 2000). Jika kebijakan setelah diimplementasi memberikan manfaat kepada masyarakat, maka itulah yang disebut kebijakan yang efektif. Atau dengan kata lain "suatu kebijakan akan menjadi efektif apabila dilaksanakan dan mempunyai dampak positif bagi masyarakat" (Islamy, dikutip Iskandar, 2005). Dengan demikian, untuk mengefektifkan setiap kebijakan dan implementasinya maka tetap harus memperkirakan apakah kebijakan itu memberi manfaat bagi masyarakat atau sebaliknya.

\section{SIMPULAN}

Berdasarkan pembahasan dan untuk menjawab permasalahan yaitu bagaimana dampak pengelolaan dan penggunaan Dana Desa terhadap pembangunan daerah, maka 
dapat disimpulkan bahwa pengelolaan dan penggunaan Dana Desa tidak memberi dampak signifikan bagi pertumbuhan pembangunan daerah dan nyatanya program pembangunan Desa tidak sinkron dengan kebijakan pembangunan Daerah (RPJM Daerah). Dampak ini disebabkan Desa sebagaimana diatur berdasarkan UU No. 6 Tahun 2014 tentang Desa, memiliki kewenangan luas dalam menentukan rencana programnya sehingga daerah kesulitan mengintegrasikan kebijakan program pembangunan. Oleh karena itu, untuk mengintegrasikan program pembangunan Desa sinkron dengan kebijakan pembangunan Daerah diperlukan intervensi regulation Pemerintah Daerah guna mengarahkan program Desa mengacu pada kebijakan pembangunan Daerah.

\section{DAFTAR PUSTAKA}

Anderson, J.E. (2006). Public Policy-making: An Introduction, Boston: Houghton Miffin Company

Berg, B.L. (2007). Qualitative Research for The Social Sciences, Boston: Pearson Education, Inc.

Creswell, J.W. (2009). Research Design: Pendekatan Kualitatif - Kuantitatif - dan Mixed, Yogyakarta: Pustaka Pelajar.

Dye, T.R. (2005). Eleventh Edition, Undestanding Public Policy, New Jersey: Pearson Prentice Hall.

Fredericksen, G.H. \& Smith, K.B. Christopher W. Larimer, and Michael J. Licari 2012. The Public Administration Theory Primer. Westview Press. USA

Indiahono, D. (2017). Kebijakan Publik Berbasis Dynamic Policy Analysis, Yogyakarta: Penerbit Gava Media

Jamaluddin, Y. (2016). “Kebijakan Dana Desa Dalam Perspektif Teori Pilihan Rasional", Procceding of International Conference on Multidisciplinary Research (ICMR) 2016, Hasanuddin University, South Sulawesi, Indonesia, ISBN 9786029977110 hal. 4954.
Jamaluddin, Y. (2016). "Pengelolaan Dana Desa Di Indonesia (Antara Harapan \& Kenyataan)", Proceeding Seminar Dan Lokakarya Nasional Indonesian Association For Public Administration SUMUT-NAD, IAPA SUMUTNAD, ISBN 979-458-910-1

Lester, J.P. \& Stewart, J. (2000). Public Policy: an Evolutionary Approach. Australia: Wodsworth, Second Edition.

Madani, M. (2011). Dimensi Interaksi Aktor Dalam Proses Perumusan Kebijakan Publik, Yogyakarta: Graha Ilmu

Makmur. (2015). Efektivitas Kebijakan Kelembagaan Pengawasan, Bandung: Refika Aditama.

Nugroho, R. (2016). Kebijakan Publik Di Indonesia, Yogyakarta: Pustaka Pelajar

Paavola, M. (2012). " The Impact of Village Development Funds on Community Welfare in the Lao People's Democratic Republic ", Faculty of Agriculture and Forestry of the University of Helsinki, Finlandia, Publisher: Viikki Tropical Resources Institute (VITRI) University of Helsinki, Finland, ISBN 978-95210-7609-1, ISSN 0786-8170.

Pusat Kajian dan Pendidikan dan Pelatihan Aparatur-I (PKP2A-1) Lembaga Administrasi Negara RI, 2017

Robertson, B. Joelene, C. \& Dunn, L. (2015). "Local Development Funds in Myanmar: An Initial Review", Discussion paper no. 9, The Myanmar Development Resource Institute's Centre for Economic and Social Development (MDRICESD) and The Asia Foundation

Rusli, B. (2014). Kebijakan Publik: Membangun Pelayanan Publik yang Responsif, Bandung: Adoya Mitra Sejahtera.

Setiorini, Y.D. (2013). Evaluasi Kebijakan Penataan Organisasi Perangkat Daerah di Lingkungan Pemerintah Kabupaten Kutai Barat, Bandung: Program Pascasarjana FISIP Unpad

Setiyono, B. (2014). Pemerintahan Dan Manejemen Sektor Publik, Jakarta: PT. BUKU SERU

Solekhan, M. (2014). Penyelenggaraan Pemerintahan Desa, Malang: Setara Press.

\section{Dokumen lainnya:}

Undang-Undang No. 6 Tahun 2014 tentang Desa

Peraturan Pemerintah No. 60 Tahun 2014 tentang Dana Desa bersumber dari Anggaran Pendapatan dan Belanja Negara

DPMD Kabupaten Garut, 2017, Laporan Konsolidasi dan realisasi penggunaan Dana Desa

\section{Web Page :}

http://www.tribunnews.com/nasional/2015>[04/ 16/2016] 
Yanhar Jamaluddin, Asep Sumaryana, Budiman Rusli \& Rd. Ahmad Buchari, Analisis

http://www.kemenDesa.go.id/index.php/view/det il/1679/penggunaan-dana-Desa> [04/13/2016]

http://www.djpk.depkeu.go.id/wpcontent/uploads/2016/11/RINCIANALOKASI-DANA-DESA-TA-2017UPLOAD.pdf>[06/04/2017]

https://bisnis.liputan6.com/ponggok_jadi_contoh_ keberhasilan $>[11 / 04 / 2017]$ https://sulteng.antaranews.com/desa_kalukubula pengelola_dana_desa_terbaik $>[11 / 04 / 2017]$ https://kupastuntas.co/ labuhan_ ratu_baru_di_lampung_timur $>$ [11/04/2017]

http://news.liputan6.com/read/2342666/kpkbanya-dana-desa-tidak-sesuaiperuntukkannya $>[10 / 17 / 2015]$

http://Liputan6.com>[03/10/2016]

https://suara.com/bisnis/pengelola_ dana_desa >[11/04/2017] 